\title{
The beneficial effects of rehabilitation on hand function in patients with rheumatoid arthritis
}

\section{Krystyna Księżopolska-Orłowskaㅁ, Teresa Sadura-Sieklucka ${ }^{1}$, Katarzyna Kasprzak ${ }^{1}$, Ewa Gaszewska ${ }^{1}$, Agnieszka Rodkiewicz-Bogusławska ${ }^{1}$, Beata Sokołowska ${ }^{2}$}

${ }^{1}$ Department of Rehabilitation in Rheumatology, National Institute of Geriatrics, Rheumatology and Rehabilitation, Warsaw, Poland ${ }^{2}$ Mossakowski Medical Research Centre, Polish Academy of Sciences, Warsaw, Poland

\begin{abstract}
Objectives: The hand is one of the main elements of the rehabilitation of patients with rheumatoid arthritis (RA) due to deformities, which occur in approximately $90 \%$ of patients. It is a serious problem, both in the psychological and functional aspect, connected with muscle strength reduction, a limited range of motion and non-acceptance of the changes in the shape of the limb. The study aimed to assess the effect of rehabilitation on the function of the hand in rheumatoid arthritis. Material and methods: The study group consisted of 40 women with RA. The patients had been previously treated at the Rehabilitation Department of the National Institute of Geriatrics, Rheumatology and Rehabilitation in Warsaw. The study group underwent 3 weeks of rehabilitation involving individual therapy, exercises with equipment, patient education and physical therapy. The control group included women without a diagnosis of RA, hands pain-free and fully mobile. In both groups the hand was assessed for grip value, grip quality and manipulative ability. In the study group the basis of pain intensity was noted. The measurements were performed twice - prior to the rehabilitation and after 3 weeks of rehabilitation in women with RA and once in women without hand problems.

Results: The results obtained revealed marked limitation of hand function in patients with rheumatoid arthritis. The treatment resulted in an improvement of all assessed parameters except cylindrical grip, in which only a part of the findings was statistically significant.

Conclusions: The analysis of the study material showed that appropriately adjusted and conducted hand physiotherapy in women with rheumatoid arthritis contributed to the improvement of its function by pain reduction, improved value and quality of grip, and also increased manipulative ability.
\end{abstract}

Key words: rheumatoid hand, rehabilitation, hand function.

\section{Introduction}

Rheumatoid arthritis (RA) is a chronic inflammatory systemic disease. The immunological process within the connective tissue contributes to progressive disability. It starts in the synovial membrane and leads to a gradual deterioration of articular and periarticular structures and deformity development. Problems which are constantly experienced by RA patients include morning joint stiffness and reduced muscle strength. The first symptoms are symmetrical carpal and metacarpophalangeal arthritis manifested by pain, oedema, exudate and a limited range of motion. Progressive hand dysfunction contributes to various limitations in the personal, social and professional aspects of life [1-3]. Pain is the dominant symptom reported by patients. Rheumatic pain is chronic and lasts from the onset of the disease until the end of a patient's life [4]. The inflammatory process and

\section{Address for correspondence}

Teresa Sadura-Sieklucka, Department of Rehabilitation in Rheumatology, National Institute of Geriatrics, Rheumatology and Rehabilitation, Spartanska 1, 02-637 Warsaw, Poland, e-mail: kko@post.pl

Submitted: 17.11.2016; Accepted: 14.12.2016 
progressive deformities reduce the functional capacity of the patient. Diminishing symptom intensity and improving locomotor functions to minimize disability are the main aims of rehabilitation [5]. Rehabilitation is a long-term process depending on the grade and type of deformity and activity of disease [6, 7]. Exercises which strengthen muscles and increase joint mobility have proved beneficial. Exercise intensity needs to be constantly controlled and adjusted to the activity of disease. During the exacerbations the exercises should be performed in hospital or on an outpatient basis under strict supervision of a therapist. Numerous therapeutic regimens may be introduced during the chronic stage. However, they should comprise both the dysfunctions and individual needs of the patient, including professional activity or hobbies. Irrespective of the activity of disease, it is extremely important to teach the patient how to behave and perform activities of daily living in a safe way in order to limit excessive joint loading. The improved function of the hand may be maintained with the continuation of an exercise programme at home [8, 9]. Functional assessment is a basic tool to determine hand dysfunction severity.

\section{Aim of the study}

The study aimed to assess the effect of 3 weeks of rehabilitation on hand function in women with rheumatoid arthritis.

\section{Material and methods \\ Patients}

The study group consisted of 40 patients. Inclusion criteria were: right-handed women with rheumatoid arthritis, grade I, II and III hand deformity according to the Seyfried classification. There were no modifications of pharmacological treatment for 3 months prior to the study. Exclusion criteria were as follows: history of sur-

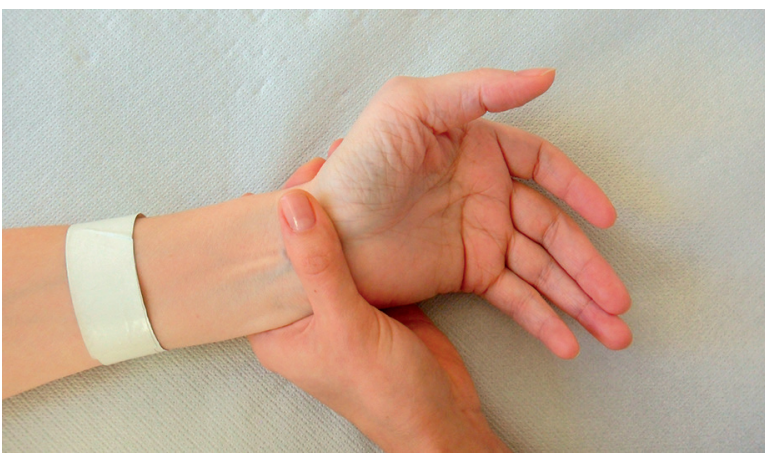

Fig. 1. Rheumatoid hand - ulnar deviation. gical procedures, injuries or other hand pathologies independent of RA. The average age in the group was 58 \pm 13 years. The study group underwent 3 weeks of rehabilitation involving individual therapy, exercises with equipment, patient education and physical therapy. Individual therapy lasted approximately 30 minutes, 5 times a week and involved joint mobilization, soft tissue techniques (Figs. 1, 2), active exercises and exercises with resistance.

All the patients for about one hour every day performed exercises with equipment such as massaging devices, cylindrical devices, balls and sponges (various sizes and elasticity). Patient education included the types and rules of performing exercises at home, learning appropriate positioning exercises and the techniques of performing the activities of daily living. Kinesiotherapy was complemented with physical therapy, involving cryotherapy (twice daily, approximately 3 minutes each session) or iontophoresis (15 minutes). The control group included 40 right-handed women (average age $52 \pm 16$ ) who had no diagnosis of inflammatory joint disease, were pain-free and had normal hand function. All the participants gave their informed consent for the study. The study was approved by the Bioethics Committee of the Institute of Rheumatology in Warsaw on September $25^{\text {th }}, 2008$.

\section{Methods}

Both groups underwent the assessment of grip value, grip quality and manipulative ability. In the study group the basis of pain intensity was noted. The measurements were performed twice - prior to the rehabilitation and after 3 weeks of rehabilitation in women with RA and once in women without hand problems. Full hand function is characterized by no pain, normal grip value and quality, and manipulative ability. Pain was assessed with the visual analogue scale (VAS). The patients indicated the intensity of their symptoms on a horizontal axis marked with numbers from 0 to 10 (the

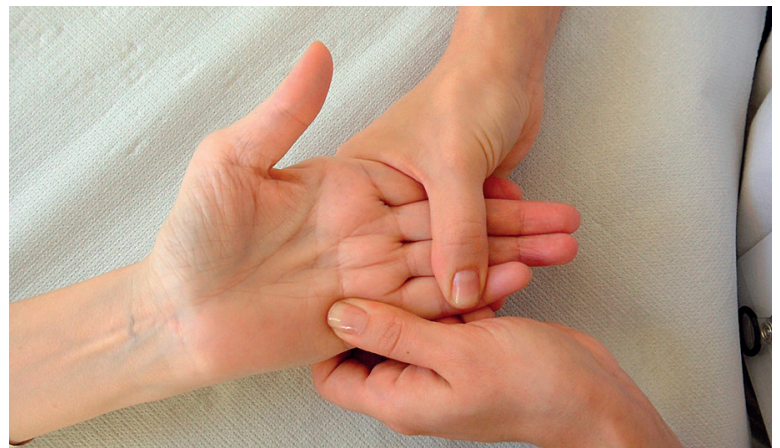

Fig. 2. Individual therapy - hypothenar soft tissue techniques. 
numbers one centimetre apart), with 0 meaning no pain and 10 meaning the worst, unbearable pain.

Grip value assessment was performed via the measurement of hand strength in an open and closed position. Grip value is the ability to carry external loading which is determined by muscle strength. Hand strength measurement during the closed position was performed with a dynamometer in which hand pressure exerted on the sensor produced proportional pressure value in the hydraulic measurement system. The pressure is expressed as force units thanks to an electronic system composed of an electronic sensor which was connected to Hercules software. The dynamometer was calibrated in kilograms of force $(\mathrm{kG})$. The open position was assessed with a manometer measuring the strength of individual fingers. The measurement specified the pressure on the basis of superficial pressure on the airbag connected to the manometer. The manometer was calibrated in millimetres of mercury ( $\mathrm{mm} \mathrm{Hg}$ ). Grip quality is the ability to fit an object in the hand. It is determined by the normal range of motion of joints.

We analyzed the cylindrical grip, which is most commonly used in everyday life. The quality of the cylindrical grip was assessed using wooden cylindrical objects which were $2.5 \mathrm{~cm}, 5 \mathrm{~cm}$ and $10 \mathrm{~cm}$ in diameter. The Seyfried assessment method was used, i.e. 100\% meant that the whole palm and all the fingers adhered to the object while gripping. We subtracted $20 \%$ for each non-adhering hand structure (fingers and metacarpus). Manipulative ability is determined by normal function of the nervous system and appropriate structure of dynamic systems of the hand. It is closely connected with the value and quality of the grip. Limited manipulative ability in RA is associated with the progressive destruction of active and passive structures of the hand and pain. It was assessed on the basis of two tests. The first one, related to grip quality, consisted in counting small balls shifted from place to place over 10 seconds. We used a board measuring $42 \mathrm{~cm} \times 28 \mathrm{~cm}$ with 30 balls $(1.8 \mathrm{~cm}$ in diameter) arranged in 5 rows, 6 balls each, $4 \mathrm{~cm}$ apart. The patients were asked to move as many balls as possible into an indentation which was $11 \mathrm{~cm}$ in diameter. The second test, related to grip value, measured the number of full rotations (opening and closing) of a lock over 10 seconds. A "Yale" lock was used as a measurement device in this test. The test was performed twice, with the better result being registered.

Statistical analysis was carried out in Statistica 10PL software. Statistical significance of the differences between measured parameters (variables) was assessed with non-parametric tests. The Wilcoxon signed-rank test and $\chi^{2}$ test were used to assess the effects before and after the rehabilitation in the study group. The Mann-Whitney $U$ test was used to compare the parameters obtained in the study and control group. The level of statistical significance was assumed at $p<0.05$.

\section{Results}

After the rehabilitation, 24 out of 40 patients in the study group reported reduced pain intensity (60\%), 10 patients (25\%) reported no changes of symptoms and in the remaining 6 patients $(15 \%)$ the pain became more severe (Table I, columns 5, 7, 9). After the rehabilitation, 6 women (15\% of the total number of results) reported pain at the level of $0-6$. There were no similar results before the rehabilitation (Table I, columns 2 and 3). The number of subjects with level 2 of pain on the VAS scale doubled after the rehabilitation (from 4 to 8 - which constituted $20 \%$ of all the reports). The majority of results were between 3 and 6 on the pain scale. As regards this range, the number of women decreased from 33 prior to the rehabilitation to 24 after the therapy (from $82.5 \%$ to $60 \%$ ). Severe pain (7-10 on the VAS scale) was reported by 3 women before the rehabilitation and by 2 (5\%) women (7 and 8 points) after the rehabilitation. However, the highest values (i.e. 9 and 10) were not re-

Table I. Numerical distribution of VAS scale results in patients with rheumatoid arthritis before and after rehabilitation

\begin{tabular}{|c|c|c|c|c|c|c|c|c|}
\hline \multirow[t]{3}{*}{ Pain scale } & \multirow{2}{*}{\multicolumn{2}{|c|}{$\begin{array}{l}\text { Total distribution } \\
\text { - number }\end{array}$}} & \multicolumn{6}{|c|}{ Assessment of pain intensity } \\
\hline & & & \multicolumn{2}{|c|}{ Decreased } & \multicolumn{2}{|c|}{ Unchanged } & \multicolumn{2}{|c|}{ Increased } \\
\hline & Before & After & Before & After & Before & After & Before & After \\
\hline $0-1$ & 0 & 6 & 0 & 6 & 0 & 0 & 0 & 0 \\
\hline 2 & 4 & 8 & 1 & 6 & 2 & 2 & 1 & 0 \\
\hline $3-6$ & 33 & 24 & 20 & 11 & 8 & 8 & 5 & 5 \\
\hline $7-10$ & 3 & 2 & 3 & 1 & 0 & 0 & 0 & 1 \\
\hline \multirow[t]{2}{*}{ Total } & 40 & 40 & 24 & 24 & 10 & 10 & 6 & 6 \\
\hline & \multicolumn{2}{|c|}{$p=0.030$} & \multicolumn{2}{|c|}{$p=0.004$} & \multicolumn{2}{|c|}{ - } & \multicolumn{2}{|c|}{$p=0.368$} \\
\hline
\end{tabular}


Table II. Strength of the whole hand and individual fingers before and after rehabilitation in the study group and in the control group

\begin{tabular}{|c|c|c|c|c|}
\hline \multicolumn{2}{|c|}{ Strength } & \multicolumn{3}{|c|}{ Right hand } \\
\hline & & Before & After & Control \\
\hline Dynamometric & & $11.0 \pm 5.6$ & $12.7 \pm 6.7^{\star}$ & $28.2 \pm 6.2^{\# \# \#,+++}$ \\
\hline \multirow{5}{*}{ Manometric } & Finger I & $17.0 \pm 11.2$ & $22.3 \pm 12.8^{\star \star \star}$ & $54.7 \pm 19.6^{\# \# \#,++++}$ \\
\hline & Finger II & $17.3 \pm 11.6$ & $23.5 \pm 13.5^{\text {***}}$ & $55.6 \pm 22.7^{\# \# \#,+++}$ \\
\hline & Finger III & $17.1 \pm 11.6$ & $24.1 \pm 18.3^{* \star *}$ & $49.7 \pm 20.5^{\# \# \#,+++}$ \\
\hline & Finger IV & $11.6 \pm 9.4$ & $14.7 \pm 15.1^{\star}$ & $32.2 \pm 12.2^{\# \# \#,+++}$ \\
\hline & Finger V & $9.6 \pm 7.4$ & $11.7 \pm 1.5^{\star}$ & $21.5 \pm 8.7^{\# \# \#,++++}$ \\
\hline \multirow{2}{*}{\multicolumn{2}{|c|}{ Strength }} & \multicolumn{3}{|c|}{ Left hand } \\
\hline & & Before & After & Control \\
\hline Dynamometric & & $9.0 \pm 5.8$ & $10.5 \pm 6.1^{\star \star}$ & $25.6 \pm 6.5^{\# \# \#,+++}$ \\
\hline \multirow[t]{5}{*}{ Manometric } & Finger I & $16.2 \pm 11.8$ & $23.2 \pm 14.8^{\star \star *}$ & $51.9 \pm 20.7^{\# \# \#,+++}$ \\
\hline & Finger II & $15.6 \pm 11.7$ & $21.6 \pm 15.3^{\star \star \star}$ & $53.7 \pm 21.3^{\# \# \#,++++}$ \\
\hline & Finger III & $14.5 \pm 11.3$ & $19.9 \pm 15.2^{* * *}$ & $46.6 \pm 17.5^{\# \# \#,+++}$ \\
\hline & Finger IV & $10.3 \pm 8.1$ & $14.9 \pm 13.7^{\star \star \star \star}$ & $32.5 \pm 14.1^{\# \# \#,+++}$ \\
\hline & Finger $\mathrm{V}$ & $8.6 \pm 8.0$ & $12.2 \pm 11.0^{\star \star \star *}$ & $25.0 \pm 11.2^{\# \# \#,+++}$ \\
\hline
\end{tabular}

${ }^{* *} p<0.01,{ }^{* * *} p<0.001$ comparison before and after rehabilitation

$\#$ \#\# 0.001 comparison control vs. before rehabilitation

${ }^{++} p<0.001$ comparison control vs. after rehabilitation

Table III. Cylindrical grip quality before and after 3 weeks of rehabilitation

\begin{tabular}{|lcccc|}
\hline \multirow{2}{*}{ Variable } & \multicolumn{2}{c|}{ Right hand } & \multicolumn{2}{c|}{ Left hand } \\
\cline { 2 - 5 } & Before rehabilitation & After rehabilitation & Before rehabilitation & After rehabilitation \\
\hline Cylinder $2.5 \mathrm{~cm}$ & $96.4 \pm 11.6$ & $98.2 \pm 7.2$ & $92.3 \pm 16.8$ & $95.5 \pm 12.8^{\star}$ \\
\hline Cylinder $5 \mathrm{~cm}$ & $98.2 \pm 5.8$ & $99.6 \pm 3.0$ & $96.4 \pm 9.9$ & $98.6 \pm 5.1^{\star}$ \\
\hline Cylinder $10 \mathrm{~cm}$ & $90.9 \pm 10.1$ & $91.8 \pm 10.0$ & $90.9 \pm 11.0$ & $92.3 \pm 10.8$ \\
\hline
\end{tabular}

${ }^{*} p<0.05$ comparison before and after rehabilitation

Table IV. The results of handling capabilities of rheumatoid hand before and after rehabilitation and healthy hand

\begin{tabular}{|c|c|c|c|c|c|c|}
\hline \multirow[t]{2}{*}{ Variable } & \multicolumn{3}{|c|}{ Right hand } & \multicolumn{3}{|c|}{ Left hand } \\
\hline & Before & After & Control & Before & After & Control \\
\hline $\begin{array}{l}\text { Shifting small balls } \\
\text { from place to place }\end{array}$ & $14.8 \pm 4.5$ & $17.2 \pm 4.6^{\star \star \star}$ & $20.6 \pm 3.1^{\# \# \#,+++}$ & $14.5 \pm 4.0$ & $16.6 \pm 4.3^{\star * *}$ & $20.4 \pm 3.2^{\# \# \#,+++}$ \\
\hline Lock rotation & $8.0 \pm 4.2$ & $11.1 \pm 5.7^{\star \star \star}$ & $18.6 \pm 5.3^{\# \# \#,+++}$ & $6.4 \pm 3.9$ & $9.4 \pm 5.2^{\star * \star}$ & $18.2 \pm 5.2^{\# \# \#,+++}$ \\
\hline
\end{tabular}

${ }_{* * *} p<0.001$ comparison before and after rehabilitation

$\# \# p<0.001$ comparison control vs. before rehabilitation

${ }^{++} p<0.001$ comparison control vs. after rehabilitation

ported. This favourable distribution of pain assessment following rehabilitation is statistically significant.

The comparison of the strength of the whole hand and the strength of each finger before and after rehabilitation between the study group and the controls revealed a major and statistically significant deficit of strength in RA patients $(p<0.001)$. Dynamometric force
- closed position activity (in kG) - increased significantly after the rehabilitation in the left and right hands in the study group (Table II). The strength of individual fingers - open position activity (in $\mathrm{mm} \mathrm{Hg}$ ) - also significantly improved.

The rehabilitation produced no significant improvement in grip quality (cylindrical grip) except grip diame- 
ter of 2.5 and $5 \mathrm{~cm}$ in the left hand (Table III). Right-handed women were qualified for the study. It may mean that the left hand was less active in everyday life. Therefore, the range of motion in the joints markedly improved. The analysis of the number of patients whose grip quality was reduced revealed that a cylinder of $10 \mathrm{~cm}$ in diameter was the most problematic to grip for approximately $40 \%$ of patients. A 5 -centimetre cylinder was the easiest to grip. The only problem related to its adhering to the right palm in $10 \%$ and to the left palm in $15 \%$ of patients. As regards the 2.5 -centimetre cylinder, the reduction of a full grip was observed in $12.5 \%$ of right and $22.5 \%$ of left hands. Therefore, it would be advisable to use the diameter of $5 \mathrm{~cm}$ to thicken the objects of everyday use in order to minimize hand overloading which results from using thin objects.

Manipulative ability assessed on the basis of two tests (the number of "lock rotations" and the number of balls shifted from place to place over 10 seconds) improved after the rehabilitation in the study group. The differences between the control group and the group of RA patients are particularly visible in the "lock rotation" test. All the results are statistically significant, as presented in Table IV.

\section{Discussion}

The paper presents disproportions between the function of a healthy and rheumatoid hand and the importance of rehabilitation in RA patients. The deformities of the hand, which has both sensory and motor functions, produce limitations in the personal, social and professional life. Pain is the dominant symptom reported by patients, and it is experienced until the end of their lives. Apart from morning joint stiffness and reduced muscle strength, pain is the main cause of reduced mobility and the ability to function independently [10, 11].

According to Drużbicki et al. [12], hand mobility significantly determines the level of disability in RA patients. Rehabilitation alleviates pain, reduces oedema and exudate in joints, improves hand function via increasing the range of motion, strengthening muscles, restoring normal mobility stereotypes and producing normal compensation. Reduced pain was observed in our study group - before the rehabilitation the average VAS score was 4.40, while after the rehabilitation it decreased to 3.43 .

Similar results were obtained by Bączyk and Klijewska [13]. Kądziołka et al. [10] reported pain reduction in all patients after physiotherapeutic treatment. The study of Ronen et al. [14] also confirmed the validity of our observation. The paper indicates a marked reduction as regards the hand and individual fingers in the patients.
Similar results were obtained by Sadura-Sieklucka in a group of 104 patients. It was proved that the maximum hand strength of women with rheumatoid arthritis translated into $39 \%$ of strength in the healthy right hand and $42 \%$ in the healthy left hand [15]. The present authors confirmed a significant influence of kinesiotherapy on the function of rheumatoid hand.

Łukowicz et al. [16] emphasized that manual exercises increase the range of motion, muscle strength, and functional capabilities of hands and reduce pain. Numerous articles published in English have reported improved hand function following rehabilitation without any exacerbation of symptoms $[17,18]$. It is necessary to continue the training programme at home, because it strengthens the therapeutic effect and prevents the development of deformities.

De Jong et al. [19] pointed out the safety of long-lasting exercise programmes without any changes visible on X-ray images. Apart from manual exercises, physical therapy procedures (cryotherapy and iontophoresis) greatly reduce pain and improve hand function. Physical therapy prepares the hand for motor rehabilitation [20]. Krawczyk-Wasielewska et al. [21] reported pain reduction as a result of iontophoresis. According to Księżopolska-Pietrzak [22] and Wójcik and Tomczak [23], cryotherapy alleviated the symptoms and shortened the duration of morning stiffness. Jones et al. [24] emphasized that the assessment of rheumatoid hand strength is a constant measurement component. The present study comparing grip value, grip quality and manipulative ability in healthy individuals and RA patients demonstrated a marked difference in the functional capacity of the hand.

A study by Brorsson [25] confirmed that grip strength is lower in RA patients than in healthy individuals. The improvement observed after the therapy confirms the necessity to implement rehabilitation in persons without any functional disorders in the course of rheumatoid arthritis. This study shows the improvement in grip quality in the left hand (the one which is used less frequently in everyday life), which additionally confirms the need to exercise. Study group patients were right-handed and performed more activities with the right hand in everyday life. Therefore, post-rehabilitation improvement concerning the range of motion was less visible in the right than in the left hand.

\section{Conclusions}

Rehabilitation is an effective treatment method in RA patients, as it reduces pain and improves rheumatoid hand function. It should be implemented as early as possible after the diagnosis is made in order to deceler- 
ate the process of joint mobility and muscle strength re duction, and the development of deformity. It should be an integral component of co-operation with RA patients.

The authors declare no conflict of interest.

\section{References}

1. Zimmermann-Górska I. Choroby reumatyczne. Podręcznik dla lekarzy i studentów. Wydawnictwo Lekarskie PZWL, Warszawa 2000.

2. Zimmermann-Górska I. Reumatologia kliniczna. Wydawnictwo Lekarskie PZWL, Warszawa 2008.

3. Głuszko P, Filipowicz-Sosnowska A, Tłustochowicz W. Reumatoidalne zapalenie stawów. Reumatologia 2012; 50: 83-90.

4. Tłustochowicz W. Ból w chorobach stawów. Termedia, Poznań 2010.

5. Hagner W. Ręka reumatoidalna. Uniwersytet Mikołaja Kopernika w Toruniu, Bydgoszcz 2006.

6. Seyfried A. Rehabilitacja osób z chorobami reumatologicznymi. In: Rehabilitacja Medyczna. Dega W, Milanowska K (eds.). Wydawnictwo Lekarskie PZWL, Warszawa 1994; 402412.

7. David C, Lloyd J. Rheumatological Physiotherapy. Mosby, London 1998.

8. Sadura-Sieklucka T. Ręka reumatoidalna. In: Fizjoterapia w reumatologii, Księżopolska-Orłowska K (ed.). Wydawnictwo Lekarskie PZWL, Warszawa 2013; 121-135.

9. Kujawa J, Gworys K. Fizjoterapia w reumatologii. In: Fizjoterapia w wybranych dziedzinach medycyny. Olszewski J (ed.). Wydawnictwo Lekarskie PZWL, Warszawa 2013; 290-310.

10. Kądziołka J, Grzegorczyk J, Rawska A. Wpływ fizjoterapii na poziom odczuwanego bólu u chorych na reumatoidalne zapalenie stawów. Przegląd Medycyny Uniwersytetu Rzeszowskiego, Rzeszów 2009; 1: 46-54.

11. Jones E, Hanly J, Mooney R, et al. Strength and function in the normal and rheumatoid hand. J Rheumatol 1991; 18: 1313 1318

12. Drużbicki M, Zwolińska J, Przysada G, et al. Assessment of hand mobility in patients with rheumatoid arthritis using a computer measures station. Reumatologia 2013; 51: 133138
13. Bączyk G, Klijewska M. Wpływ rehabilitacji na funkcjonowanie i jakość życia chorych z reumatoidalnym zapaleniem stawów. Nowiny Lekarskie 2005; 74: 123-126.

14. Ronen R, Braun Z. A community-oriented programme for rehabilitation of person with arthritis. Disabil Rehabil 1996; 18: 476-481.

15. Sadura-Sieklucka T. Wpływ stabilizacji nadgarstka na funkcję ręki w reumatoidalnym zapaleniu stawów. Praca doktorska, Warszawski Uniwersytet Medyczny 2014.

16. Łukowicz M, Bieleń R, Zalewski P, Weber-Zimmermann M. Wpływ ćwiczeń manualnych na funkcję ręki reumatycznych. Acta Balneologica 2007; 49: 281-287.

17. Buljina A, Taljanovic M, Avdic D, et al. Physical and Exercise Therapy for Treatment of the Rheumatoid Hand. Arthritis Rheum 2001; 45: 392-397.

18. Brorsson S, Hilliges $\mathrm{M}$, Sollerman $\mathrm{Ch}$, et al. A six-week hand exercise programme improves strength and hand function in patients with rheumatoid arthritis. J Rehabil Med 2009; 41: 338-342.

19. De Jong Z, Munneke M, Zwinderman A, et al. Long term high intensity exercise and damage of small joint in rheumatoid arthritis. Ann Rheum Dis 2004; 63: 1399-1405.

20. Księżopolska-Orłowska K, Krasowicz-Towalska O, Wroński Z. Rehabilitacja pacjentów z chorobami reumatycznymi. Reumatologia 2007; 45 (supl. 1): 41-45.

21. Krawczyk-Wasielewska A, Kuncewicz E, Sobieska M, et al. Ocena skuteczności fizjoterapii w uśmierzaniu bólu towarzyszącego reumatoidalnemu zapaleniu stawów. Nowa Medycyna 2007; 4: 74-79.

22. Księżopolska-Pietrzak K. Krioterapia w leczeniu chorób reumatycznych. Ortopedia, Traumatologia i Rehabilitacja 2000; 2: 66-69.

23. Wójcik P, Tomczak H. Wpływ krioterapii miejscowej na leczenie bólu w reumatoidalnym zapaleniu stawów. Fam Med Prim Care Rev 2007; 9: 645-649.

24. Jones E, Hanly J, Mooney R, et al. Strenght and function in the normal and rheumatoid hand. J Rheumatology 1991; 18: 1313-1318.

25. Brorsson S, Nilsdotter A, Pedersen E, et al. Relationship between finger flexion end extension force in healthy women and women with rheumatoid arthritis. J Rehabil Med 2012; 44: 605-608. 